Article

\title{
Impact of ovarian fetal tissue xenotransplantation associated with in vitro embryo production in annual genetic gain estimates for cattle weight traits
}

\author{
Rafaella Kelly Silva ${ }^{1}$, Luiza Rodrigues Alves Abreu², \\ Filipe Luiz Januzzi Valente ${ }^{3}$, Giovanna Faria de Moraes ${ }^{1 *}$
}

\begin{abstract}
The present paper aims to estimate the impact of the reduction of the generation interval, based on the model of fetal ovarian tissue xenotransplantation associated with in vitro embryo production to estimate the annual genetic gain of weight traits in a bovine herd. Weigh data and genealogy of Brahman animals were used to estimate the annual direct genetic gain for weight at birth, weight at 120 days, at 210 days, and at 550 days of age. The genetic parameters were obtained by animal model, via Bayesian inference, by Markov Chain Monte Carlo (MCMC) methods. For the estimates, different generation intervals were defined as the average value between the supposed maternal generation intervals and the average sire generation interval based on the analyzed data (9.6 years). The shortest generation interval considered was 5.1 years, outlined from the average of 0.66 year (corresponds to 8 fetal months, an assumption defined based on the use of fetal ovarian tissue xenotransplantation associated with in vitro embryo production) and 9.6 years (sire generation interval). The remaining intervals considered were 6.7, 8.7 and 10.2 years. The estimate of annual direct genetic gain for all the evaluated traits was higher when considering the generation interval outlined based on the model of fetal ovarian tissue xenotransplantation associated with in vitro embryo production. The estimates were lower as the generation interval increased. The use of fetal ovarian tissue xenotransplantation associated with in vitro embryo production, may favor the reduction of the generation interval and successively generate a positive impact on the annual direct genetic gain estimates.
\end{abstract}

Keywords: Biotechnology, Brahman, heritability, generation interval.

\footnotetext{
${ }^{1}$ Faculdade de Medicina Veterinária, Universidade Federal de Uberlândia - UFU. Uberlândia, MG Brasil.

2 Escola de Veterinária, Universidade Federal de Minas Gerais - UFMG. Belo Horizonte, MG Brasil.

${ }^{3}$ Fundação Educacional D. André Arcoverde, Centro de Ensino Superior de Valença-CESVA. Valença, RJ - Brasil

* corresponding author: g.f.moraes@hotmail.com
} 


\section{Introduction}

The estimate of expected direct genetic gain in a trait under selection consists in the heritable portion of the difference between the average of the group of animals selected for next generation parents, and the average of the entire population (PEREIRA, 2014). It is represented by " $\Delta \mathrm{G}$ " and directly depends on the selection intensity (1), heritability $\left(h^{2}\right)$ and phenotypic standard deviation $\left(\sigma_{p}\right)$, and inversely on the generation interval (L) (LIRA et al., 2013). The generation interval, defined as the time that elapses between the birth of the animal and its progeny (CARNEIRO JUNIOR, 2009), will then impact the genetic evolution of the herd and their productivity.

It is expected that a high interval of generations will result in less genetic gain, and thus, less economic return and genetic progress of animal breeding programs (MALHADO et al., 2008). High generation intervals result from the use of old animals as breeders, a situation that can be aggravated by the inadequate mating strategies by encouraging the use of old bulls' genetic material through artificial insemination. However, when well applied, biotechnologies tend to support the genetic progress. An example of this kind of well application is the use of reproductive tissue xenotransplantation. According to Barros et al. (2014), xenotransplantation is the process of collecting tissue from an animal of one species and inserting it into a receptor of another. The use of this biotechnology in cattle breeding intends to minimize the loss of ovarian follicles from high genetic value females, in order to use existing oocytes in ovaries that would be sentenced to low utilization, or even to disposal, in cases of donor death (BEZERRA et al., 2011).

When performed with fetal bovine ovarian tissue, xenotransplantation may optimize the use of genetic material from high genetic value female calves even before birth, as in cases of pregnant cow death during the gestation (MORAES et al., 2018). In the future, with the use of this 
xenotransplanted material for the in vitro embryo production (IVEP) it is expected that there will be genetic progress in traits of economic impact, such as weight traits, present in several animal breeding programs.

Measurement and selection for weight traits, such as birth weight (BW), weight at 120, 210, and 550 days of age (W120, W210, and W550, respectively), are essential, because producers seek animals that have fast development and growth, which shortens the production cycle, and enables greater economic return (BOLIGON et al., 2009). In this context, the aim was to estimate the impact of the reduction of the generation interval, based on the model of xenotransplantation of fetal ovarian tissue associated with IVEP to estimate the annual genetic direct gain of weight traits in a bovine herd.

\section{Methodology}

Data from Brahman cattle provided by a breeding farm located in Uberlândia (State of Minas Gerais, Brazil) were analyzed. The data provided refers to weights' traits collected between 2005 and 2017, and also included genealogical information of all animals with phenotypic data. Initially, the phenotypic database consisted of 1482 birth weights (BW), 826 weights at 120 days of age (W120), 948 weights at 210 days of age (W210), and 804 weights at 550 days of age (W550).

After data consistency analysis and formation of contemporary groups (CG), performed in the SAS 9.0 software, data of BW from 1438 animals, W120 from 800 animals, W210 from 931 animals, and W550 from 786 animals were included in the analysis. As it is a herd which carries out the commercialization of animals with high genetic potential, there is a different amount of data per animal. The CG was defined by concatenating the effects of sex, time, and year of birth. Time of birth was considered: Rainy = January, February, March, October, November, and December, and Dry = April, May, June, July, August, and September. CG with less than 
three animals and data 3.5 standard deviations above or below the characteristic average were excluded. Then, $28 \mathrm{CG}$ were used in the analysis of the trait BW, 41 CG in the analysis of the W120 trait, 44 CG in the analysis of the W210 trait, and 37 CG in the analysis of the W550 trait.

The relationship matrix used in the analysis was constructed from the pedigree information of the animals with phenotypic data, constituting a database of 4,306 animals. The variation component was estimated by Bayesian inference, using Markov Chain Monte Carlo (MCMC) methods, in the GIBBS1F90 program (MISZTAL et al., 2014), using animal model in single-trait analysis. The model used for BW, W120 and W210 is represented in matrix notation as: $Y=X \beta+Z_{1} a+Z_{2} m+e$ while the model used for W550 is represented in matrix notation as: $Y=X \beta+Z_{1} a+e$, in which $Y$ represents the vector of $\mathrm{n}$ observations, $\beta$ represents the solution vector of fixed effects; $a$ represents the solution vector for the additive direct genetic effects; $m$ represents the solution vector of maternal additive genetic effects, $e$ denotes the vector of residual effect, and $X, Z_{1}$ and $Z_{2}$ denotes the incidence matrices related to $\beta, a$ and $m$, respectively. The vectors $a$ and $e$ were considered independent. In Bayesian analysis, vectors $B$ and $a$ are parameters for locating a conditional distribution $Y / B$, a. It was considered, a priori, that $B$ has a uniform distribution that reflects vague prior knowledge about this solution vector. Thus, the distribution of $Y$, given the parameters of location and scale, was considered as: $Y / B, a, R \sim N[X \beta+Z a$ + IR] (MORAES et al., 2017).

Samples of a posteriori distributions of variance estimates were generated from 1,100,000 cycles, in which the first 100,000 were discarded, and the samples stored at every 100 cycles. The convergence was checked with the graphic inspection of the sampled values versus interactions and by the criterion proposed by Geweke (1992). This criterion was estimated using the Bayesian Output Analysis (BOA) statistical package of the $\mathrm{R}$ program ( $\mathrm{R}$ Core Team, 2015). For all traits, 
the a posteriori distribution means, estimated at each analysis, were used for the posteriori mean heritability $\left(h^{2}\right)$ estimation.

Samples of the posteriori distributions of annual direct genetic gain were obtained from the samples of the variance components. Selection of $5 \%$ was initially considered (selection intensity $=2.06$ ). The responses to direct selection (annual direct genetic gain) were calculated as the following equation: $\Delta G_{h}=\frac{i_{h} h_{h}^{2} \sigma_{p_{h}}}{L}$ in which: $\Delta G_{h}$ is the expected annual direct genetic gain for the trait in question, $i_{h}$ is the selection intensity, $h_{h}^{2}$ is the heritability of the selected trait, $\sigma_{p_{h}}$ is the phenotypic standard deviation corresponding to the selected trait (LIRA et al., 2013), and L represents the generation interval.

The generation interval between 2005 and 2017 was calculated as the average time that elapsed between the birth of the parents (sire and dam) and their progenies (CARNEIRO JUNIOR, 2009), with the average paternal age at the birth of the progeny being 9.6 years. To define the generation intervals used in the annual direct genetic gain calculations, the fetal ovarian tissue xenotransplantation methodology (MORAES et al., 2018) associated with IVEP was used as a model, so that biotechnology represented inspiration for the mathematic model of the smallest generation interval outlined. For that, time was standardized in months and then transformed into years. When the generation interval between the mother and the progeny is three years, for example, this data should be interpreted as three years of age plus nine months of fetal life for this animal, therefore, 45 months or 3.75 years.

Therefore, the groups of generation intervals used in the annual direct genetic gain calculations were defined as the average between the supposed maternal generation intervals and the average paternal generation interval based on the analyzed data (9.6 years). In this context, 
Table 1 shows the different average generation intervals outlined to be used in annual direct genetic gain equation.

Table 1 - Average generation intervals outlined to be used in annual direct genetic gain equation, based on the average value between the supposed maternal generation intervals and the paternal generation interval.

\begin{tabular}{ccc}
\hline Outlined L & Maternal L (supposed) & Paternal L \\
\hline 5.1 years & 0.66 years $=8$ fetal months $*$ & 9.6 years \\
6.7 years & 3.75 years $=3$ years +9 fetal months & 9.6 years \\
8.7 years & 7.75 years $=7$ years +9 fetal months & 9.6 years \\
10.2 years & 10.75 years $=10$ years +9 fetal months & 9.6 years
\end{tabular}

$\overline{\mathrm{L}}=$ generation interval; $* 8$ fetal months $=$ definition based on the use of fetal ovarian tissue xenotransplantation biotechnology associated with in vitro embryo production.

\section{Results and discussion}

The results of mean phenotypic values and standard deviations for the analyzed traits in this study (Table 2) were similar to other studies that also studied Brahman (BONIFÁCIO et al., 2009; FARIA et al., 2011; MAGNABOSCO et al., 2017). Weight traits and weight gain at different ages are good indicators of animals' growth potential, and as they have medium to high magnitude heritability values, they stand out as selection criteria in breeding genetic programs (LAUREANO et al., 2011).

Magnabosco et al. (2017), also evaluating Brahman animals, demonstrated that male calves have higher BW $(36.6 \pm 1.9 \mathrm{~kg})$ than female calves $(35.8 \pm 1.8 \mathrm{~kg})$, values higher than those found in this study. A few years ago, Holland and Odde (1992) already pointed out that when they are too small at birth, calves may lack vigor, tolerance to thermal stress, or resistance to pathological agents, while when they are too big at birth they can cause degrees of dystocia, leading to increased asphyxia at birth, metabolic and respiratory acidosis, in addition to depressed immunoglobulin 
absorption and increased susceptibility to disease.

The W120 is related to milk production and the quantity offered to the calf (JUNG et al., 2012). According to Paneto et al. (2002), this trait demonstrates the potential for weight gain and, therefore, allows for the selection of precocious animals. W210, or weaning weight, according to Ribeiro et al. (2004), is a measure related to the annual production of the beef cow. Weight gains achieved up to that period have lower cost than those obtained at older ages. Bonifácio et al. (2009) reported W210 of $191.5 \pm$ $32.3 \mathrm{~kg}$ - values lower than those found in this study - for animals born from 2001 to 2009, which were participants of the Genetic Improvement Program of the Brahman breed. For W550, Faria et al. (2011) reported similar values $(338.2 \pm 77.8 \mathrm{~kg}$ ) to those found in this study (Table 2). These facts demonstrate that the farm that provided the data, between 2005 and 2017 had satisfactory results for the evaluated weight traits, probably due to the fact that these are criteria of the selection objective.

Table 2 - Means, standard deviation (SD), and confidence interval (CI 95\%) of the evaluated traits in Brahman cattle, and posterior means of additive genetic variances, residual variances, phenotypic variances and heritability, estimated by single-trait analyses.

\begin{tabular}{llllllll}
\hline Trait & N & Mean \pm SD & CI 95\% & $\boldsymbol{\sigma}^{\mathbf{a}}$ & $\boldsymbol{\sigma}^{\mathbf{e}} \boldsymbol{\boldsymbol { \sigma } ^ { \mathbf { p } } \boldsymbol { p }}$ & $\boldsymbol{h}^{\mathbf{2}}$ \\
\hline BW & 1438 & $34.2 \pm 4.8$ & $33.9-34.5$ & 12.0 & 11.28 & 21.9 & 0.54 \\
W120 & 800 & $127.1 \pm 33.8$ & $124.8-129.4$ & 295.9 & 313.1 & 567.3 & 0.51 \\
W210 & 931 & $217.6 \pm 30.5$ & $215.6-219.6$ & 698.9 & 693.0 & 1286.3 & 0.54 \\
W550 & 786 & $332.7 \pm 99.9$ & $325.7-339.7$ & 1197.9 & 3219.3 & 4417.2 & 0.27
\end{tabular}

$\mathrm{N}=$ number; $\mathrm{BW}=$ Weight at Birth (kg); W120 = Weight at 120 days of age (kg); W210 = Weight at 210 days of age $(\mathrm{kg}) ; \mathrm{W} 550=$ Weight at 550 days of age $(\mathrm{kg}) ; \mathrm{n}=$ number; $\sigma^{2} a=$ additive genetic variance; $\sigma^{2} e=$ residual variance; $\sigma^{2} p=$ phenotypic variance; $h^{2}=$ direct heritability; $\mathrm{kg}=$ kilogram

The additive genetic variance values, and the heritability estimates (Table 2) demonstrate that the studied traits are able to satisfactorily respond to the selection process. The heritability estimates obtained were 
medium to high magnitude, which suggests that the genetic difference between individuals is responsible for a large part of the variation of the trait. Therefore, as selection criteria, they tend to generate responses in a short period of time. In Faria et al. (2011)'s studies with Brahman animals, heritability estimates for BW, W120, W210, and W550 were also of medium to high magnitude. It is worth mentioning that heritability is not a fixed parameter, varying according to the specificities of the population, and the environment in question (PEREIRA, 2014).

It is important to highlight that the Brahman breed is relatively new in Brazil, aging 26 years. In 1994, the Brazilian Breeders Association of Zebu (ABCZ), registered the first two Brahman animals that started the formation of the national herd (ACBB). When a breed or a herd have a selection program for a trait for several years, there is a tendency of decreasing the genetic variance of the herd, making the population more homogeneous, which can result in low heritability estimates. Thus, a strategy to maintain high heritability estimates is to insert genetic variance in the herd (PEREIRA, 2014), and reduce residual variance, i.e., to minimize non-genetic factors, with standardization of the environment and formation of contemporary groups (LAUREANO et al., 2011).

The mean of generation interval \pm standard deviation for the herd in the study was $7.5 \pm 5.0$ years, which corroborates with the results of Bonifácio et al. (2009). The average age of dam and sires at the birth of their calf, in the studied population (progeny born between 2005 and 2017) was $5.4 \pm 2.4$ and $9.6 \pm 5.9$ years, respectively. It is worth noting that in the analyzed database, in recent years the average age of sires at the birth of their calves has shown a decreasing tendency, and several of those recent intervals were 2 to 4 years. The selection for sexual precocity is being carried out in the analyzed herd, encouraging the use of precocious animals as breeders, especially in recent years. The use of genetically superior young sires is an essential tool for reducing the generation interval (BONIFÁCIO 
et al., 2009). Reproductive precocity is fundamental in cattle breeding, as it allows greater productive use of the animal, in addition to increasing the rate of genetic progress, by reducing the generation interval, as well as decreasing the cost of the animal (CORDEIRO et al., 2016).

The estimate of annual direct genetic gain for all evaluated traits was higher when considering the generation interval of 5.1 years, outlined from the supposed maternal generation interval of 0.66 year or 8 fetal months, based on the model of fetal ovarian tissue xenotransplantation associated with IVEP (Table 3). As there was an increase in the outlined generation intervals, there was a decrease in the estimates of annual direct genetic gain for all the analyzed weight traits (Graph 1). Malhado et al. (2008), points out that reducing generation interval in breeding programs increases the genetic gain, and consequently provides a greater economic return to the producer. It is worth noting that if the time elapsed between the birth of the parents (sire and dam) and their progenies was lower, the estimates of genetic gains would be even higher.

Table 3- Estimated annual direct genetic gain for weight traits evaluated in Brahman cattle, according to different outlined generation intervals.

\begin{tabular}{lllll}
\hline Generation intervals & $\Delta \mathrm{GBW}$ & $\Delta \mathrm{GW} 120$ & $\Delta \mathrm{GW} 210$ & $\Delta \mathrm{GW} 550$ \\
\hline 5.1 years & 1.01 & 4.85 & 7.74 & 7.17 \\
6.7 years & 0.77 & 3.73 & 5.95 & 5.51 \\
8.7 years & 0.59 & 2.87 & 4.58 & 4.25 \\
10.2 years & 0.51 & 2.45 & 3.91 & 3.62 \\
\hline
\end{tabular}

$\Delta \mathrm{GBW}=$ Annual direct genetic gain for birth weight (kg); $\Delta \mathrm{GW} 120=$ Annual direct genetic gain for weight at 120 days of age $(\mathrm{kg}) ; \Delta \mathrm{GW} 210=$ Annual direct genetic gain for weight at

210 days of age $(\mathrm{kg}) ; \Delta \mathrm{GW} 550=$ Annual direct genetic gain for weight at 550 days of age (kg). $\mathrm{kg}=$ kilogram.

Graph 1 - Estimated annual direct genetic gain for weight traits evaluated in the Brahman cattle, according to different outlined generation intervals. 


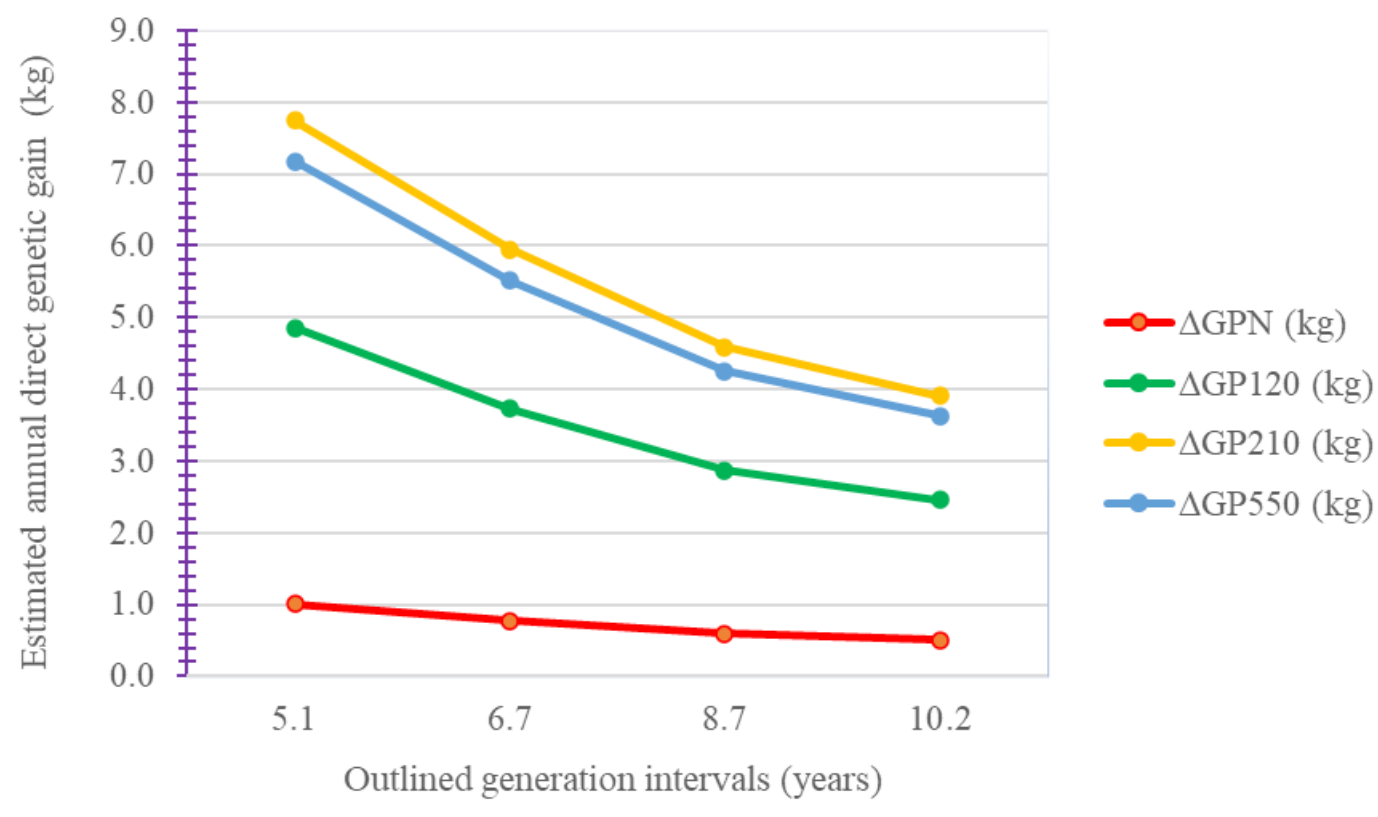

$\Delta \mathrm{GBW}=$ Annual direct genetic gain for birth weight; $\Delta \mathrm{GW} 120=$ Annual direct genetic gain for weight at 120 days of age; $\Delta \mathrm{GW} 210=$ Annual direct genetic gain for weight at 210 days of age; $\Delta \mathrm{GW} 550=$ Annual direct genetic gain for weight at 550 days of age. $\mathrm{kg}=$ kilogram

Fetal bovine ovarian tissue xenotransplantation has the potential to enable the in vivo cultivation of ovarian follicles in another recipient species (FIGUEIREDO et al., 2008), so that they can subsequently be submitted to other reproductive biotechnologies. Studies of Bezerra et al. (2011), conducted with fetal bovine ovaries, showed that there was activation of primordial follicles, with spontaneous growth of preantral ovarian follicles and emergence of antral follicles after 30 days of transplantation with oocytes of appropriate size for in vitro maturation. This situation demonstrates that follicles from fetal bovine ovarian tissue xenotransplantation could be submitted to maturation and later to in vitro fertilization. Thus, in the future it is expected that it will be possible to perform in vitro embryo production, resulting from material from this culture. The association of these biotechnologies will then allow for the shortest possible generation interval, significantly increasing the estimates of the annual genetic gain of the herds, and consequently the productivity of the cattle. 


\title{
Conclusion
}

The use of the biotechnology fetal ovarian tissue xenotransplantation associated with the in vitro embryo production, may favor the reduction of the generation interval and successfully generate a positive impact on the annual direct genetic gain estimates.

\section{Acknowledgement}

To Uberbrahman Farm for providing the data.

\section{$* * *$ \\ Impacto do xenotransplante de tecido ovariano fetal associado à produção in vitro de embriões em estimativas de ganho genético anual para características de peso em bovinos}

\begin{abstract}
Resumo: O presente estudo teve como objetivo estimar o impacto da redução do intervalo de gerações, com base no modelo de xenotransplante de tecido ovariano fetal associado à produção in vitro de embriões, na estimativa do ganho genético anual direto de características de peso em um rebanho bovino. Dados de pesagens e genealogia de animais da raça Brahman foram utilizados para estimar o ganho genético direto anual para as características peso ao nascimento, peso aos 120 dias, aos 210 dias e aos 550 dias de idade. Os parâmetros genéticos foram obtidos por modelo animal, via inferência Bayesiana, por Métodos de Monte Carlo via Cadeias de Markov. Para as estimativas, foram delineados intervalos de gerações distintos, definidos como a média entre os supostos intervalos de gerações materno e o intervalo de gerações paterno médio do rebanho analisado $(9,6$ anos). O menor intervalo de gerações considerado foi 5,1 anos, resultante da média entre 0,66 ano (corresponde a 8 meses fetais, suposição definida com base na utilização da biotecnologia xenotransplante de tecido ovariano fetal associada à produção in vitro de embriões) e 9,6 anos. Os demais intervalos considerados foram 6,7, 8,7 e 10,2 anos. A estimativa do ganho genético anual para todas as características avaliadas foi superior quando se considerou o intervalo de gerações delineado com base no modelo de xenotransplante de tecido ovariano fetal associado à produção in vitro de embriões. As estimativas foram menores conforme aumento no intervalo de gerações. O uso da biotecnologia xenotransplante de tecido ovariano fetal, associada à produção in vitro de embriões poderá favorecer a redução
\end{abstract}


do intervalo de gerações e sucessivamente gerar impacto positivo nas estimativas de ganho genético direto anual.

Palavras-chave: Biotecnologia, Brahman, herdabilidade, intervalo de gerações.

\section{References}

ACBB. Associação dos Criadores de Brahman do Brasil, [s.d.]. A história da ACBB Disponível em: https://brahman.com.br/associacao/a-historia-da-acbb

BARROS, F. F. P. C.; TEIXEIRA, P. P. M.; SIlVA, M. A. M.; SILVA, A. S. L.; MEDEIROS, R. M.; COELHO, C. M. M.; BANDARRA, M. B., MACEDO, M. F.; BEZERRA, M. B.; VICENTE, W. R. R. Xenotransplante em camundongos Imunossuprimidos coletado por meio de ovariectomia unilateral total vídeolaparoscópica em ovelha. Revista Brasileira de Reprodução Animal, v. 38, n. 2, p. 121-126, 2014. Disponível em: http://cbra.org.br/pages/publicacoes/rbra/v38n2/pag121$\underline{126 \% 20(\mathrm{RB} 492) . \mathrm{pdf}}$

BEZERRA, M. B.; PACHECO, M. R.; MINGOTI, G. Z.; MACEDO, M. F.; VICENTE, W. R. R. Potencial do cultivo in vitro e do xenotransplante na sobrevida e no desenvolvimento de folículos ovarianos pré-antrais em matrizes de ruminantes domésticos em risco de morte: revisão de literatura. Revista Brasileira de Reprodução Animal, v. 35, n. 4, p. 483-489, 2011. Disponível em: https://cbra.websiteseguro.com/pages/publicacoes/rbra/v35n4/pag\%20483-489.pdf

BOLigON, A. A.; ALBUQUERQUE, L. G. D.; MERCADANTE, M. E. Z.; LÔBO, R. B. Herdabilidades e correlações entre pesos do nascimento à idade adulta em rebanhos da raça Nelore. Revista Brasileira de Zootecnia, v. 38, n. 12, p. 2320-2326, 2009. https://doi.org/10.1590/S1516-35982009001200005

BONIfÁCIO, A., LEITE, J., RAYMUNDO, A., DE FARIA, L. C., \& LÔBO, R. B. Progresso genético e intervalo de gerações na raça Brahman no Brasil. 2009. Disponível em: https://ancp.org.br/up artigos/351tico).pdf 
CARNEIRO JUNIOR, J. M. Melhoramento genético animal. In: GONCALVES, R. C.; DE OLIVEIRA, L. C. Embrapa Acre: ciência e tecnologia para o desenvolvimento sustentável do Sudoeste da Amazônia. Rio Branco, AC: Embrapa Acre, 2009. cap. 11, p. 197-208.

CORDEIRO, A. L., SOUZA, F. A., \& SATRAPA, R. A. Novilhas sexualmente precoces: Fisiologia e Importância econômica. Revista Portuguesa de Ciências Veterinárias, v. 111, n. 599, p. 1-9,2016. Disponível em: http://www.spcv.pt/download/Vol111/Vol111-n599-600.pdf

FARIA, L. C.; QUEIROZ, S. A.; VOZZI, P. A.; LÔBO, R. B.; BEZERRA, L. A. F.; MAGNABOSCO, C. U.; OLIVEIRA, E. J. A. Quantitative genetic study on growth traits of Brahman cattle in Brazil. Ars Veterinaria, v. 27, n. 1, p. 030-035, 2011. http://dx.doi.org/10.15361/2175-0106.2011v27n1p030-035

FIGUEIREDO, J. R. D., RIBEIRO RODRIGUES, A. P., \& ANDRADE AMORIM, C. Manipulação de oócitos inclusos em folículos ovarianos pré-antrais. In: GONÇALVES, P. B. D.; FIGUEIREDO, J. R. de; FREITAS, V. J. F. Biotécnicas aplicadas à reprodução animal. São Paulo: Livraria Roca, 2008. p.227-260. Disponível em: http://hdl.handle.net/2078.1/136444

GEWEKE, J. Evaluating the accuracy of sampling-based approaches to the calculation of posterior moments. Bayesian Statistical, v. 4, n. 1, p. 169-193, 1992. https://doi=10.1.1.27.2952\&rep=rep1\&type

HOLLAND, M. D.; ODDE, K. G. Factors affecting calf birth weight: a review. Theriogenology, v. 38, n. 5, p. 769-798, 1992. https://doi.org/10.1016/0093$\underline{691 X(92) 90155-\mathrm{K}}$

JUNG, L. C. S.; REZENDA, L. O. F.; MAGNABOSCO, C. de U.; LOPES, F. B.; MAMEDE, M. M. Efeito da idade da vaca sobre peso ao nascimento calculado aos 120 e 210 dias de idade de um rebanho de bovinos da raça Nelore. In: Embrapa 
Cerrados-Artigo em anais de congresso (ALICE). In: REUNIÃO ANUAL DA SOCIEDADE BRASILEIRA DE ZOOTECNIA, 49., 2012, Brasília. A produção animal no mundo em transformação: anais. Brasília, DF: SBZ, 2012. Disponível em: http://www.alice.cnptia.embrapa.br/alice/handle/doc/930140

LAUREANO, M. M. M.; BOLIGNON, A. A.; COSTA, R. B.; FORNI, S.; SEVERO, J. L. P.; ALBUQUERQUE, L. G. Estimativas de herdabilidade e tendências genéticas para características de crescimento e reprodutivas em bovinos da raça Nelore. Arquivo Brasileiro de Medicina Veterinária e Zootecnia, v. 63, n. 1, p. 143-152, 2011. https://doi.org/10.1590/S0102-09352011000100022

LIRA, T. S de.; PEREIRA, L. de S.; LOPES, F. B.; FERREIRA, J. L.; LÔBO, R. B.; SANTOS, G. C. de J. Tendências genéticas para características de crescimento em rebanhos Nelore criados na região do Trópico Úmido do Brasil. Ciência Animal Brasileira, v. 14, n. 1, p. 23-31, 2013. https://doi.org/10.5216/cab.v14i1.16785

MAGNABOSCO, C. U.; LOPES, F. B.; BRUNES, L. C.; SOUZA, F. M.; MAMEDE, M. M. S.; SANTOS, M. F. dos; QUEIROZ, L. C. R.; BORGES JUNIOR, A. R.; CARVAlHO, M. A. A. de; COSTA, M. F. O. e; EIFERT, E. da C. Estimativa do peso ao nascimento em bovinos das raças Brahman e Nelore Mocho por meio do perímetro torácico. Embrapa Cerrados-Boletim de Pesquisa e Desenvolvimento (INFOTECA-E), $2017 . \quad$ Disponível em: https://ainfo.cnptia.embrapa.br/digital/bitstream/item/173419/1/Bolpd-341.pdf

MALHADO, C. H. M.; CARNEIRO, P. L. S.; PEREIRA, D. G.; MARTINS FILHO, R. Progresso genético e estrutura populacional do rebanho Nelore no Estado da Bahia. Pesquisa Agropecuária Brasileira, v. 43, n. 9, p. 1163-1169, 2008. https://doi.org/10.1590/S0100-204X2008000900010

MISZTAL, I.; LEGARRA, A; AGUILAR, I. Using recursion to compute the inverse of the genomic relationship matrix. Journal of dairy science, v. 97, n. 6, p. 39433952, 2014. https://doi.org/10.3168/jds.2013-7752 
MORAES, G. F., ABREU, L. R. A., FERREIRA, I. C., \& PEREIRA, I. G. Análise genética do consumo alimentar residual ajustado para gordura e de características de carcaça e desempenho em um rebanho Nelore. Ciência Rural, v. 47, n. 2, p. 1-6, 2017. https://doi.org/10.1590/0103-8478cr20151505.

MORAES, G. F.; RONDA, J. B.; ALVES, K. A.; ALVES, B. G.; SANTOS, R. M.; REIS, J. P. J.; FREITAS, R. A. A.; CAMPOS, B. S.; SILVA JUNIOR, E. D.; MARQUES, J. C. S.; GONTIJO, D. A.; MORAES, A. B. A. Visual evaluation of fetal bovine ovarian tissue fragments submitted to xenotransplantation.In: VII ISABR, 2018. Aracajú. Anais... Aracajú: VII ISABR, 2018.

PANETO, J.C.C.; LEMOS, D.C.; BEZERRA, L.A.F. Estudo de características quantitativas de crescimento dos 120 aos 550 dias de idade em gado Nelore. Revista Brasileira de Zootecnia, v. 31, n. 2, p. 668-674, 2002. https://doi.org/10.1590/S1516-35982002000300017

PEREIRA, J. C. C. Melhoramento genético aplicado à produção animal. 4 .ed. Belo Horizonte: FEPMVZ Editora, 2014. 758p.

R CORE TEAM. R: A language and environment for statistical computing. $R$ Foundation for Statistical Computing. Vienna, Austria, 2015. Available from: http://www.R-project.org/

RIBEIRO, A. C.; HOLANDA, M. C. R.; SANTORO, K. R.; BARBOSA, S. B. P. Tendências genéticas para crescimento em bovinos Nelore em Pernambuco, Brasil. Archivos de zootecnia, v. 53, n. 202, p. 185-194, 2004. Disponível em: https://www.redalyc.org/pdf/495/49520207.pdf

YOKOO, M. J. I.; ALBUQUERQUE, L. G. de; LÔBO, R. B.; SAINZ, R. D.; CARNEIRO JUNIOR, J. M.; BEZERRA, L. A. F.; ARAUJO, F. R. da C. Estimativas de parâmetros genéticos para altura do posterior, peso e circunferência escrotal em bovinos da raça Nelore. Revista Brasileira de Zootecnia, v. 36, n. 6, p. 1761-1768, 2007. https://doi.org/10.1590/S1516-35982007000800008 